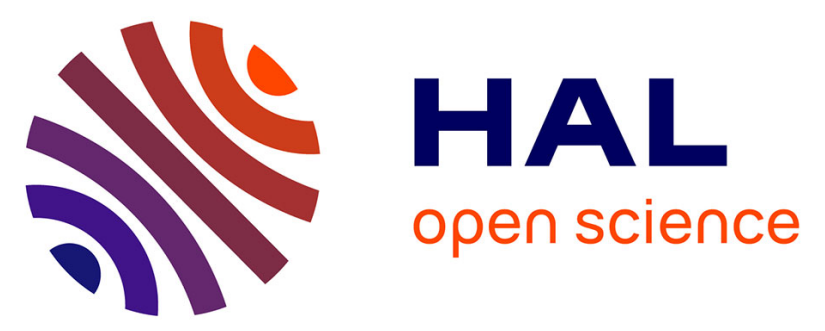

\title{
Post-mortem storage conditions and cooking methods affect long-chain omega-3 fatty acid content in Atlantic mackerel (Scomber scombrus)
}

Fany Sardenne, Eleonora Puccinelli, Marie Vagner, Laure Pecquerie, Antoine Bideau, Fabienne Le Grand, Philippe Soudant

\section{To cite this version:}

Fany Sardenne, Eleonora Puccinelli, Marie Vagner, Laure Pecquerie, Antoine Bideau, et al.. Post-mortem storage conditions and cooking methods affect long-chain omega-3 fatty acid content in Atlantic mackerel (Scomber scombrus). Food Chemistry, 2021, 359, pp.129828. 10.1016/j.foodchem.2021.129828 . hal-03215360

\author{
HAL Id: hal-03215360 \\ https://hal.science/hal-03215360
}

Submitted on 3 May 2021

HAL is a multi-disciplinary open access archive for the deposit and dissemination of scientific research documents, whether they are published or not. The documents may come from teaching and research institutions in France or abroad, or from public or private research centers.
L'archive ouverte pluridisciplinaire HAL, est destinée au dépôt et à la diffusion de documents scientifiques de niveau recherche, publiés ou non, émanant des établissements d'enseignement et de recherche français ou étrangers, des laboratoires publics ou privés. 
Post-mortem storage conditions and cooking methods affect long-chain omega-3 fatty acid content in Atlantic mackerel (Scomber scombrus)

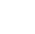

Fany Sardenne*, Eleonora Puccinelli, Marie Vagner, Laure Pecquerie, Antoine Bideau, Fabienne Le Grand, Philippe Soudant

Univ Brest, CNRS, IRD, Ifremer, LEMAR, F-29280 Plouzané, France

* $\underline{\text { fany.sardenne@univ-brest.fr }}$

\section{Abstract}

Long-chain omega-3 fatty acids such as eicosapentaenoic acid (EPA) and docosahexaenoic acid (DHA) are health beneficial lipids found in high concentration in pelagic fishes, including Atlantic mackerel. While EPA and DHA are sensitive to oxidative degradation during fish storage and processing, post-mortem degradation in the first hours following fish death is poorly documented. In this study, we stored fish at two temperatures $\left(2-4^{\circ} \mathrm{C}\right.$ and $18-20^{\circ} \mathrm{C}$ ) and monitored EPA+DHA content in dorsal fillet 6, 12 and 24 hours after fish death and after cooking (grill or steam). Storage duration was the most influencing factor, and EPA+DHA loss was faster at $18-20^{\circ} \mathrm{C}$. Six hours after fish death, and regardless of storage temperature EPA+DHA content decreased by $1.3 \pm 1.3 \mathrm{mg} \cdot \mathrm{g}^{-1}(9.6 \pm 9.5 \%$ of the initial content). EPA+DHA losses were highly variable among individuals, probably because of other sources of variability (e.g., sampling position). Handling between fishing operation and deep-frozen storage should be as short and as cool as possible to preserve EPA+DHA and for food safety. Regarding cooking, both EPA+DHA and mono-unsaturated fatty acids increased in grilled fillets. 
Key words: Oxidation, Fatty acids, Lipids, Small pelagic fish, Storage, Cooking method 
Long-chain n-3 polyunsaturated fatty acids, and especially eicosapentaenoic acid (EPA; 20:5n-3) and docosahexaenoic acid (DHA; 22:6n-3) are essential lipids for several vital functions in human (Siriwardhana et al., 2012; Swanson et al., 2012). Due to insufficient $d e$ novo synthesis capacities, a daily dietary EPA+DHA intake of about $300 \mathrm{mg}$ is recommended for healthy adults (FAO/WHO, 2010; Plourde \& Cunnane, 2007). Several human populations however, face an EPA+DHA deficiency, caused by malnutrition or undernutrition (Stark et al., 2016). EPA and DHA human supplies are mainly ensured by the consumption of marine fish, which obtain these lipids through the food web, mainly from primary producers. Due to climate changes that induces modifications in the physiology and community composition of primary producers (Galloway \& Winder, 2015), the global EPA+DHA production is predicted to decrease (Hixson \& Arts, 2016). Such a decrease, combined with human population growth, might cause a shortage in EPA+DHA availability that may become a challenge for human food security in the next decades (Hicks et al., 2019). Preservation of EPA+DHA in food is thus of high importance.

Small and medium pelagic fish, also called blue-backed fish, play an important role in food security, as they are cheaper than large fishes and rich in nutrients, including EPA+DHA (Kawarazuka \& Béné, 2011). Among them, the Atlantic mackerel Scomber scombrus is a fatty fish occurring in cold and temperate regions of the northern Atlantic Ocean, where it forms large schools near the surface to feed on zooplankton and small fishes. About one million tons of Atlantic mackerel are fished yearly, mainly by purse seine or pelagic trawl (FAO Fisheries \& Aquaculture, 2020). Mackerels are generally frozen or chilled whole at collection, for further processing ashore (Sone et al., 2019). Storage method and duration, fish processing, and cooking procedures are critical steps for fish EPA+DHA preservation, because EPA and DHA are highly sensitive to oxidation (Gladyshev \& Sushchik, 2019; Secci 
\& Parisi, 2016). In the case of mackerel, whose lipid content can vary by a factor of three among individuals, storage temperature is among the main factor determining a successful storage (Romotowska et al., 2017). Studies have investigated lipid changes in long-term storage of mackerel for a large panel of storage temperatures and duration, from $-27^{\circ} \mathrm{C}$ to $+26^{\circ} \mathrm{C}$ and from a day to a year (Otero et al., 2019; Oucif et al., 2012; Romotowska et al., 2016, 2017; Standal et al., 2018). However, as for many other fish species, initial reference values were based on fish obtained from commercial fishing and the exact time of death was not well documented. Consequently, having information on the EPA+DHA changes in the first post-mortem hours could help detecting EPA+DHA losses during the first processing steps of fish (e.g., between fishing and the processing plants).

The objectives of this study were to quantify in Atlantic mackerel (i) EPA+DHA changes during the first post-mortem hours according to storage temperature; and (ii) the influence of the cooking method (grill and steam) on the EPA+DHA content. Fatty acids, including EPA+DHA, were quantified in the fillet of freshly euthanized mackerel, and at 6, 12 and 24 hours from death, on fish stored at two contrasted temperatures $\left(2-4^{\circ} \mathrm{C}\right.$ and $\left.18-20^{\circ} \mathrm{C}\right)$.

\section{Material \& Method}

\subsection{Sample collection}

Fifteen mackerels Scomber scombrus $(25.2 \pm 3.3 \mathrm{~cm}, \min -\max =20-30 \mathrm{~cm}$ in fork length) were collected by hand line in the Baie de Douarnenez, France on July $26^{\text {th }} 2020$. Seawater parameters were $16.2^{\circ} \mathrm{C}$ and $34.8 \mathrm{PSU}$, and air temperature was $18-20^{\circ} \mathrm{C}$ throughout the fishing operation. Fish were immediately euthanized by immersion in a $1 \mathrm{~mL} . \mathrm{L}^{-1}$ eugenol bath (Fili@vet Reseau Cristal, France) for 5-10 min, then immediately labelled for later identification, and dissected on board. Sampling was restricted to the dorsal fillet from the right side of the fish (i.e., white muscle under the first dorsal fin).This area is homogenous in 
both lipid content and lipid oxidation in S. scombrus (Icekson et al., 1998), and in lipid and fatty acids contents in the related species S. japonicus and S. australasicus (Bae et al., 2010). In a previous estimate conducted on three Atlantic mackerels kept frozen for 8 months at $15^{\circ} \mathrm{C}$, the EPA+DHA contents varied from ca. $7 \%$ among the sampled positions (results not shown). For each fish, about $0.5 \mathrm{~g}$ wet weight (ww) of dorsal white muscle was sampled without skin, flash frozen in liquid nitrogen, and stored in a dry shipper frequently refuelled with liquid nitrogen ( $\mathrm{T}_{0}$ sample). The total time between fish death and sample flash-freezing was less than 10 min. Fishes were then kept whole (neither eviscerated, nor filleted), and randomly stored either (i) at about $4^{\circ} \mathrm{C}$ in an insulated styrofoam box cooled with $-20^{\circ} \mathrm{C}$ ice packs ( $\mathrm{n}=8$ fish), or (ii) at ambient temperature in a styrofoam box ( $\mathrm{n}=7$ fish). To consider the inter-individual variability, measurements were repeated over time on the same individuals. Six hours after the first tissue sampling, another $0.5 \mathrm{mg}$ ww sample of dorsal muscle was taken on each fish next to the previous one $\left(\mathrm{T}_{6}\right)$ (Fig.1). Samples were flash frozen and stored in a dry shipper, and fishes were stored back in their respective box (i.e., ice packs or ambient). The same procedure was repeated 12 and 24 hours after the first tissue sampling ( $\mathrm{T}_{12}$ and $\mathrm{T}_{24}$, respectively) (Fig.1). Air temperature of the storage boxes (i.e., ice cold or ambient temperature) was recorded before each tissue sampling and ranked $2-4^{\circ} \mathrm{C}$ and $18-20^{\circ} \mathrm{C}$ throughout the storage test, respectively.

After the last sampling, dorsal fillet from the left side was filleted and cooked on ethanolcleaned equipment, with neither oil nor condiment. Fillets with skin were either (i) grilled on a griddle at $80-90^{\circ} \mathrm{C}$ for five minutes, or (ii) steamed with $130 \mathrm{~mL}$ of tap water brought to a boil for 15 minutes (for each cooking method, half individuals were from each storage temperatures; Fig.1). European populations commonly used these two methods, steaming being particularly preferred for babies. After cooking, about $0.5 \mathrm{mg}$ ww of fillet without skin 
was collected, flash frozen, and stored in a dry shipper. All the samples were then stored at $80^{\circ} \mathrm{C}$ for 40 days before subsequent analyses.

\subsection{Moisture analysis}

Moisture was determined by gravimetry. Samples were weighed before and after a 65 -hours freeze-drying (Christ Alpha 1-2 LD plus lyophilizer). The mean analytical variability was $1 \%$. Immediately after freeze-drying, samples were homogenized with ball mill (Restch MM400) and stored back at $-80^{\circ} \mathrm{C}$ for four days before lipid extraction. Moisture was expressed in percentage of wet weight.

\subsection{Fatty acid analysis}

Lipids were extracted from ca. $60 \mathrm{mg}$ of dry powder with $6 \mathrm{~mL}$ of solvent mixture $\left(\mathrm{CH}_{3} \mathrm{Cl}_{3}: \mathrm{MeOH}, 2: 1, \mathrm{v}: \mathrm{v}\right)$ directly added into glass vials (Sardenne et al., 2019). Extracts were flushed with nitrogen gas, vortexed, sonicated for $15 \mathrm{~min}$, and stored for 15 days at $-20^{\circ} \mathrm{C}$. Tricosanoic acid (23:0) was added as internal standard to lipid extract. Lipids were then transesterified with $\mathrm{H}_{2} \mathrm{SO}_{4}(3.8 \%$ in $\mathrm{MeOH})$ at $100^{\circ} \mathrm{C}$ for 10 min. Fatty acid methyl esters (FAME) were separated and quantified on a Varian CP8400 gas chromatograph (GC) equipped in parallel with a Zebron ZB-WAX and a ZB-5HT column (both $30 \mathrm{~m}$ length, 0.25 $\mathrm{mm}$ internal diameter, $0.25 \mu \mathrm{m}$ film thickness; Phenomenex) and flame ionisation detectors at the Lipidocean core facility, University of Brest, France. GC parameters were set as in Sardenne et al. (2019). FAME were identified by comparing sample retention times to those of commercial standard mixtures (Supelco 37-component FAME mix, BAME, and PUFA no. 1 and 3 mixes; Sigma-Aldrich) using Galaxie 1.9.3.2 software (Varian). FAME content was converted into fatty acids (FA) content based on 23:0 recovery. Total FA content was 
calculated as the sum of 41 identified FA (16 poly-unsaturated FA (PUFA), 15 monounsaturated FA (MUFA), and 10 saturated FA (SFA)). Data were expressed in $\mathrm{mg}^{-\mathrm{g}^{-1}}$ dry weight to avoid confounding lipid changing content with water changing content. The mean analytical variability was $4.2 \%$ for the GC and $11.9 \%$ for the whole FA analysis.

\subsection{Data analysis}

Contents in moisture, total FA, EPA+DHA, and FA families (SFA, MUFA, PUFA) were compared among storage temperatures, durations and the interaction between both factors tested using semi-parametric MANOVAs for repeated measures based on a central $\chi^{2}$ distribution, which does not assume multivariate normality nor covariance homogeneity (RM function from the 'MANOVA.RM' package; Friedrich et al., 2018). Non-parametric paired Wilcoxon tests (V statistic) were used to refine differences between duration modalities. Unpaired Wilcoxon test (W statistic) were used to test for differences between storage temperatures at each duration, and between cooking modes. Spearman correlation tests ( $\mathrm{S}$ statistic) were used to test for correlation between EPA+DHA losses at $\mathrm{T}_{6}, \mathrm{~T}_{12}$, and $\mathrm{T}_{24}$, and FA content at $T_{0}$, and linear regressions were used to test for fish length influence on FA contents. Data were analysed using R software 3.5.0 (R Development Core Team et al., 2018), and 'stats' and 'MANOVA.RM' packages.

\section{Results}

Initial EPA+DHA content was $16.2 \pm 4.0 \mathrm{mg} . \mathrm{g}^{-1} \mathrm{dw}$ ), representing about $30 \%$ and $80 \%$ of total FA and PUFA, respectively. The amount of FA varied as a function of fish length, with larger individuals having a higher content of total FA and EPA+DHA (i.e. from $12.2 \pm 0.2$ to 17.6 $\pm 0.6 \mathrm{mg} \cdot \mathrm{g}^{-1}$ between 20 and $30 \mathrm{~cm}$ in fork length ; Fig 2). Biochemical contents of fish, including EPA+DHA (Table 1), changed with storage duration, but was not affected neither 
by storage temperature nor by the interaction between storage temperature and duration (Table 2). Changes in EPA+DHA content between storage conditions were highly variable among individuals (large SD; Table 1).

Regardless of the storage temperature, total FA content decreased between $T_{0}$ and $T_{24}$, from $60.9 \pm 21.8$ to $51.0 \pm 24.1 \mathrm{mg} \cdot \mathrm{g}^{-1}(\mathrm{~V}=114, \mathrm{p}<0.001$; Table 1 , Fig. $3 b)$. Variability in total FA content (estimated through coefficients of variation) was lower at $2-4^{\circ} \mathrm{C}$ than at $18-20^{\circ} \mathrm{C}\left(\mathrm{T}_{6}\right.$ : $32.2 \%$ and $42.8 \%, \mathrm{~T}_{12}: 44.0 \%$ and $49.9 \%$, and $\mathrm{T}_{24}: 40.1 \%$ and $58.0 \%$ at $2-4^{\circ} \mathrm{C}$ and $18-20^{\circ} \mathrm{C}$, respectively). Regarding cooking, total FA content did not change from $\mathrm{T}_{24}$ in either grilled or steamed fillets $(\mathrm{W}=42, \mathrm{p}=0.12 ;$ Fig. $3 b)$.

EPA+DHA content decreased between $\mathrm{T}_{0}$ and $\mathrm{T}_{6}(\mathrm{~V}=110, \mathrm{p}<0.01)$ : paired differences indicated a loss of $1.3 \pm 1.3 \mathrm{mg} \cdot \mathrm{g}^{-1}\left(0.9 \pm 1.3\right.$ and $1.9 \pm 1.1 \mathrm{mg} \cdot \mathrm{g}^{-1}$ at $2-4^{\circ} \mathrm{C}$ and $18-20^{\circ} \mathrm{C}$, respectively), equating to a loss of $9.6 \pm 9.5 \%$ (5.5 $\pm 8.1 \%$ and $14.2 \pm 9.3 \%$, respectively) of the initial EPA+DHA content. EPA+DHA content also decreased between $\mathrm{T}_{6}$ and $\mathrm{T}_{12}(\mathrm{~V}=103$, $\mathrm{p}<0.05)$, but not after $(\mathrm{V}=61, \mathrm{p}=0.98$; Fig. $3 \mathrm{c})$. No correlations between total FA content at $\mathrm{T}_{0}$ and $\mathrm{EPA}+\mathrm{DHA}$ losses at $\mathrm{T}_{6}, \mathrm{~T}_{12}$, and $\mathrm{T}_{24}$ were detected $(\mathrm{S}=814, \mathrm{p}=0.10 ; \mathrm{S}=450, \mathrm{p}=0.48$; $\mathrm{S}=438, \mathrm{p}=0.43$, respectively). Regarding cooking, grilled fillet gained $3.4 \pm 3.5 \mathrm{mg} \cdot \mathrm{g}^{-1}$ and steamed fillets lost $0.2 \pm 3.4 \mathrm{mg} \cdot \mathrm{g}^{-1}$ of EPA+DHA from $\mathrm{T}_{24}(\mathrm{~W}=46, \mathrm{p}<0.05$; Table 1). As for EPA+DHA, PUFA, MUFA and SFA contents decreased between $\mathrm{T}_{0}$ and $\mathrm{T}_{6}$ (all $\mathrm{p}<0.01$; Fig. $3 d$ to $f$, but only PUFA continued to decrease between $T_{6}$ and $T_{12}(V=98, p<0.05)$. Cooking methods affected both EPA+DHA and MUFA contents, which were already lowered by storage $(\mathrm{W}=46, \mathrm{p}<0.05$ and $\mathrm{W}=47, \mathrm{p}<0.05)$ : EPA+DHA and MUFA gained $3.4 \pm 3.5$ and $5.7 \pm 5.4 \mathrm{mg} \cdot \mathrm{g}^{-1}$ in grilled fillet and lost $0.2 \pm 3.3$ and $2.3 \pm 6.3 \mathrm{mg} \cdot \mathrm{g}^{-1}$ in steamed fillet, respectively (Fig. 3c and e).

\section{Discussion}


EPA and DHA are sensitive to oxidation, but their loss during fish processing in the first postmortem hours of the Atlantic mackerel is not well documented. Here, we find that i) storage duration was the only factor explaining FA losses in the first hours after fish death, and ii) grilled fillet had higher EPA+DHA content than steamed fillet. However, changes in EPA+DHA content were highly variable among individuals, probably in relation to other sources of variability (e.g. sampling position, analytical variability).

High inter-individual variability was observed both in FA contents and in FA losses. Fish length explained most of the variability in the initial FA content, and storage duration was the only significant factor explaining FA losses, despite faster FA losses at the high storage temperature $\left(18-20^{\circ} \mathrm{C}\right)$. Other sources of variability in FA losses might be the heterogeneity in FA compositions among tissue sampling positions, despite the fact that all positions were close to each other, i.e., dorsal white muscle under the first dorsal spine. While we tested the natural variability of EPA+DHA content in the dorsal fillet of frozen Atlantic mackerel, and that this remains relatively low, this variability remains to be assessed for fresh individuals. Regarding changes due to storage duration, FA contents decreased only six hours after fish death with: $9.6 \pm 9.5 \%$ of the initial EPA+DHA content been lost. Again, the large inter-individual differences observed can be explained by the sources of variability previously mentioned (i.e., sampling position and analytical variability). However, only PUFA continued to decrease 12 hours after death. PUFA are generally considered as the FA the most sensitive to degradation, especially to oxygen contact that causes peroxidation (Couturier et al., 2020). While lipid hydrolysis tends to increase with fish fat content (Aubourg et al., 2005; Rudy et al., 2016), this relationship has not been reported for mackerel, even over several storage months (Aubourg et al., 2005). Similarly, we did not observe any relationship between the initial fish FA content and EPA+DHA losses in the first post-mortem hours of mackerel. These results highlight the importance of fast handling, and to a lesser extent of cool handling, 
even before the rigor mortis that usually occurs at about 18-21 hours post-mortem in mackerel (Anders et al., 2020). Although temperature did not play a crucial role for lipid oxidation on the short time scale of this study ( 24 hours), it is relevant for other degradation mechanisms such as hydrolysis or histamine production (Couturier et al., 2020; Zou \& Hou, 2017). Avoiding filleting, favoring fast frozen of fish, as well as the maintenance of low temperature throughout long-term storage could save highly valuable FA in the Atlantic mackerel (Aubourg et al., 2005; Romotowska et al., 2017), caveat that can probably be generalized to other fatty and small pelagic fishes (e.g., Rudy et al., 2016). This procedure is also relevant for scientific samplings of fish obtained from professional fisheries or from remote areas, which could rapidly loose FA before analysis, including EPA+DHA, due to a lack of proper storage.

Regarding cooking methods, grilled fish had higher FA contents, especially EPA+DHA and MUFA, than steamed fish, as well as than $\mathrm{T}_{0}$ fish (all in dry weight). A higher FA content measured after grilling might be related (i) to changes in the fillet texture that might improve FA extraction from tissue, as high heating is commonly used by the industry for fish oil extraction (Adeoti \& Hawboldt, 2014); or (ii) to FA exchanges with the subcutaneous fat beneath the skin (fillets were cooked with the skin), favoured by the increasing temperature. Studies have shown no exchanges of FA between fillet and skin of the Atlantic mackerel during iced and frozen storage (Xing et al., 1993), but extensive exchanges can occur during frying (Sebedio et al., 1993). In addition, the skin of small pelagic fish is relatively rich in EPA+DHA: about 19\%, 26\%, 25\% and $13 \%$ of total FA for the Atlantic mackerel, Rastrelliger kanagurta, Sardinella maderensis and Sardinella aurita, respectively (Njinkoué et al., 2002; Sahena et al., 2010; Zuta et al., 2003). This suggests that the skin should be kept to cook Atlantic mackerel fillets. Extended tests including other cooking methods should however be conducted to determine the best cooking method to preserved the 
valuable EPA+DHA from the Atlantic mackerel. Indeed, the summer Atlantic mackerel is an excellent food source of EPA+DHA: with about 4 to $5 \mathrm{mg} \cdot \mathrm{g}^{-1}$ in wet weight, a daily consumption of $75 \mathrm{~g}$ (raw or steamed) or $60 \mathrm{~g}$ (grilled) of dorsal fillet would be enough to cover the EPA+DHA daily requirements in adults.

\section{Acknowledgments}

We warmly thank J.-P. and P.-Y. Carval for welcoming us on-board for the fishing operation. We also thanks O. Gauthier (University of Brest, LEMAR) for its advices with statistics, and the two anonymous reviewers for their comments and suggestions on an earlier draft of this work. F.S. was funded by the Regional council of Brittany (SAD program), and E.P was funded by ISblue project, Interdisciplinary graduate school for the blue planet (ANR-17EURE-0015), co-funded by a grant from the French government under the program "Investissements d'Avenir" and the SAD program. This study contributes to the OMEGA project, funded by ISblue project.

\section{Author credits}

Fany Sardenne: conceptualization, methodology, software, investigation, writing - original draft, review \& editing. Eleonora Puccinelli: investigation, writing - review \& editing. Marie Vagner: writing - review \& editing, funding acquisition. Laure Pecquerie: writing - review \& editing, funding acquisition. Fabienne Le Grand: validation, resources. Antoine Bideau: methodology. Philippe Soudant: validation, writing - review \& editing, funding acquisition.

\section{References}


Adeoti, I. A., \& Hawboldt, K. (2014). A review of lipid extraction from fish processing byproduct for use as a biofuel. In Biomass and Bioenergy (Vol. 63, pp. 330-340). Elsevier Ltd. https://doi.org/10.1016/j.biombioe.2014.02.011

Anders, N., Eide, I., Lerfall, J., Roth, B., \& Breen, M. (2020). Physiological and flesh quality consequences of pre-mortem crowding stress in Atlantic mackerel (Scomber scombrus). PLoS ONE, 15(2), e0228454. https://doi.org/10.1371/journal.pone.0228454

Aubourg, S. P., Rodríguez, A., \& Gallardo, J. M. (2005). Rancidity development during frozen storage of mackerel (Scomber scombrus): effect of catching season and commercial presentation. European Journal of Lipid Science and Technology, 107(5), 316-323. https://doi.org/10.1002/ejlt.200401124

Bae, J.-H., Yoon, S.-H., \& Lim, S.-Y. (2010). A comparison of the biochemical characteristics of different anatomical regions of Chub (Scomber japonicus) and Blue mackerel (Scomber australasicus) muscles. Korean Journal of Fisheries and Aquatic Sciences, 43(1), 6-11. https://doi.org/10.5657/kfas.2010.43.1.006

Couturier, L. I. E., Michel, L. N., Amaro, T., Budge, S. M., da Costa, E., De Troch, M., Di Dato, V., Fink, P., Giraldo, C., Le Grand, F., Loaiza, I., Mathieu-Resuge, M., Nichols, P. D., Parrish, C. C., Sardenne, F., Vagner, M., Pernet, F., \& Soudant, P. (2020). State of art and best practices for fatty acid analysis in aquatic sciences. ICES Journal of Marine Science. https://doi.org/10.1093/icesjms/fsaa121

FAO/WHO. (2010). Report of the Joint FAO/WHO Expert Consultation on the Risks and Benefits of Fish Consumption. Rome, 25-29 january 2010. http://www.fao.org/3/ba0136e/ba0136e00.htm

FAO Fisheries \& Aquaculture. (2020). Species Fact Sheets - Scomber scombrus (Linnaeus, 1758). http://www.fao.org/fishery/species/2473/en 
272 Friedrich, S., Konietschke, F., \& Pauly, M. (2018). Analysis of Multivariate Data and Repeated Measures Designs with the R Package MANOVA.RM. Family Medicine, 37(5)(01), 53-65. http://arxiv.org/abs/1801.08002

Galloway, A. W. E., \& Winder, M. (2015). Partitioning the Relative Importance of Phylogeny and Environmental Conditions on Phytoplankton Fatty Acids. PLoS ONE, 10(6), e0130053. https://doi.org/10.1371/journal.pone.0130053

Gladyshev, M. I., \& Sushchik, N. N. (2019). Long-chain omega-3 polyunsaturated fatty acids in natural ecosystems and the human diet: Assumptions and challenges. In Biomolecules (Vol. 9, Issue 9, p. 485). MDPI AG. https://doi.org/10.3390/biom9090485

Hixson, S. M., \& Arts, M. T. (2016). Climate warming is predicted to reduce omega-3, longchain, polyunsaturated fatty acid production in phytoplankton. Global Change Biology, 22(8), 2744-2755. https://doi.org/10.1111/gcb.13295

Icekson, I., Drabkin, V., Aizendorf, S., \& Gelman, A. (1998). Lipid oxidation levels in different parts of the mackerel, Scomber scombrus. Journal of Aquatic Food Product Technology, 7(2), 17-29. https://doi.org/10.1300/J030v07n02_03

Kawarazuka, N., \& Béné, C. (2011). The potential role of small fish species in improving micronutrient deficiencies in developing countries: Building evidence. Public Health Nutrition, 14(11), 1927-1938. https://doi.org/10.1017/S1368980011000814

Njinkoué, J. M., Barnathan, G., Miralles, J., Gaydou, E. M., \& Samb, A. (2002). Lipids and fatty acids in muscle, liver and skin of three edible fish from the Senegalese coast: Sardinella maderensis, Sardinella aurita and Cephalopholis taeniops. Comparative Biochemistry and Physiology - B Biochemistry and Molecular Biology, 131(3), 395-402. https://doi.org/10.1016/S1096-4959(01)00506-1 
Otero, L., Pérez-Mateos, M., Holgado, F., Márquez-Ruiz, G., \& López-Caballero, M. E. (2019). Hyperbaric cold storage: Pressure as an effective tool for extending the shelf-life of refrigerated mackerel (Scomber scombrus, L.). Innovative Food Science and Emerging Technologies, 51, 41-50. https://doi.org/10.1016/j.ifset.2018.05.003

Oucif, H., Ali-Mehidi, S., \& El-Amine Abi-Ayad, S.-M. (2012). Lipid oxidation and histamine production in Atlantic Mackerel (Scomber scombrus) versus time andmode of conservation. Journal of Life Sciences, 6, 713-720.

Plourde, M., \& Cunnane, S. C. (2007). Extremely limited synthesis of long chain polyunsaturates in adults: implications for their dietary essentiality and use as supplements. Applied Physiology, Nutrition, and Metabolism, 32(4), 619-634. https://doi.org/10.1139/H07-034

R Development Core Team, Team, R. C., R Development Core Team, Team, R. C., \& R Development Core Team. (2018). R: A language and environment for statistical computing (3.5.0). R Foundation for Statistical Computing. https://doi.org/3-900051-070

Romotowska, P. E., Gudjónsdóttir, M., Karlsdóttir, M. G., Kristinsson, H. G., \& Arason, S. (2017). Stability of frozen Atlantic mackerel (Scomber scombrus) as affected by temperature abuse during transportation. LWT - Food Science and Technology, 83, 275282. https://doi.org/10.1016/J.LWT.2017.05.024

Romotowska, P. E., Karlsdóttir, M. G., Gudjónsdóttir, M., Kristinsson, H. G., \& Arason, S. (2016). Influence of feeding state and frozen storage temperature on the lipid stability of Atlantic mackerel (Scomber scombrus). International Journal of Food Science \& Technology, 51(7), 1711-1720. https://doi.org/10.1111/ijfs.13146

Rudy, M. D., Kainz, M. J., Graeve, M., Colombo, S. M., \& Arts, M. T. (2016). Handling and 
storage procedures have variable effects on fatty acid content in fishes with different lipid quantities. PLoS ONE, 11(8), e0160497. https://doi.org/10.1371/journal.pone.0160497

Sahena, F., Zaidul, I. S. M. M., Jinap, S., Yazid, A. M., Khatib, A., \& Norulaini, N. A. N. N. (2010). Fatty acid compositions of fish oil extracted from different parts of Indian mackerel (Rastrelliger kanagurta) using various techniques of supercritical $\mathrm{CO}_{2}$ extraction. Food Chemistry, 120(3), 879-885. https://doi.org/10.1016/j.foodchem.2009.10.055

Sardenne, F., Bodin, N., Metral, L., Crottier, A., Le Grand, F., Bideau, A., Brisset, B., Bourjea, J., Saraux, C., Bonhommeau, S., Kerzérho, V., Bernard, S., \& Rouyer, T. (2019). Effects of extraction method and storage of dry tissue on marine lipids and fatty acids. Analytica Chimica Acta, 1051, 82-93. https://doi.org/10.1016/J.ACA.2018.11.012

Sebedio, J. L., Ratnayake, W. M. N., Ackman, R. G., \& Prevost, J. (1993). Stability of polyunsaturated omega-3 fatty acids during deep fat frying of Atlantic mackerel (Scomber scombrus L.). Food Research International, 26(3), 163-172. https://doi.org/10.1016/0963-9969(93)90049-O

Secci, G., \& Parisi, G. (2016). From farm to fork: lipid oxidation in fish products. A review. Italian Journal of Animal Science, 15(1), 124-136. https://doi.org/10.1080/1828051X.2015.1128687

Siriwardhana, N., Kalupahana, N. S., \& Moustaid-Moussa, N. (2012). Health Benefits of n-3 Polyunsaturated Fatty Acids. Eicosapentaenoic Acid and Docosahexaenoic Acid. In Advances in Food and Nutrition Research (Vol. 65, pp. 211-222). Academic Press Inc. https://doi.org/10.1016/B978-0-12-416003-3.00013-5

Sone, I., Skåra, T., \& Olsen, S. H. (2019). Factors influencing post-mortem quality, safety and 
storage stability of mackerel species: a review. In European Food Research and Technology (Vol. 245, Issue 4, pp. 775-791). Springer Verlag. https://doi.org/10.1007/s00217-018-3222-1

Standal, I. B., Mozuraityte, R., Rustad, T., Alinasabhematabadi, L., Carlsson, N. G., \& Undeland, I. (2018). Quality of Filleted Atlantic Mackerel (Scomber Scombrus) During Chilled and Frozen Storage: Changes in Lipids, Vitamin D, Proteins, and Small Metabolites, including Biogenic Amines. Journal of Aquatic Food Product Technology, 27(3), 338-357. https://doi.org/10.1080/10498850.2018.1436107

Stark, K. D., Van Elswyk, M. E., Higgins, M. R., Weatherford, C. A., \& Salem, N. (2016). Global survey of the omega-3 fatty acids, docosahexaenoic acid and eicosapentaenoic acid in the blood stream of healthy adults. In Progress in Lipid Research (Vol. 63, pp. 132-152). Elsevier Ltd. https://doi.org/10.1016/j.plipres.2016.05.001

Swanson, D., Block, R., \& Mousa, S. A. (2012). Omega-3 Fatty Acids EPA and DHA: Health Benefits Throughout Life. Advances in Nutrition, 3(1), 1-7. https://doi.org/10.3945/an.111.000893

Xing, Y., Yoo, Y., Kelleher, S. D., Nawar, W. W., \& Hultin, H. O. (1993). Lack of changes in fatty acid composition of mackerel and cod during iced and frozen storage. Journal of Food Lipids, 1(1), 1-14. https://doi.org/10.1111/j.1745-4522.1993.tb00230.x

Zou, Y., \& Hou, X. (2017). Histamine production by enterobacter aerogenes in chub mackerel (Scomber japonicus) at various storage temperatures. Food Science and Technology, 37(1), 76-79. https://doi.org/10.1590/1678-457X.07716

Zuta, C. P., Simpson, B. K., Chan, H. M., \& Phillips, L. (2003). Concentrating PUFA from mackerel processing waste. JAOCS, Journal of the American Oil Chemists' Society, 80(9), 933-936. https://doi.org/10.1007/s11746-003-0799-5 


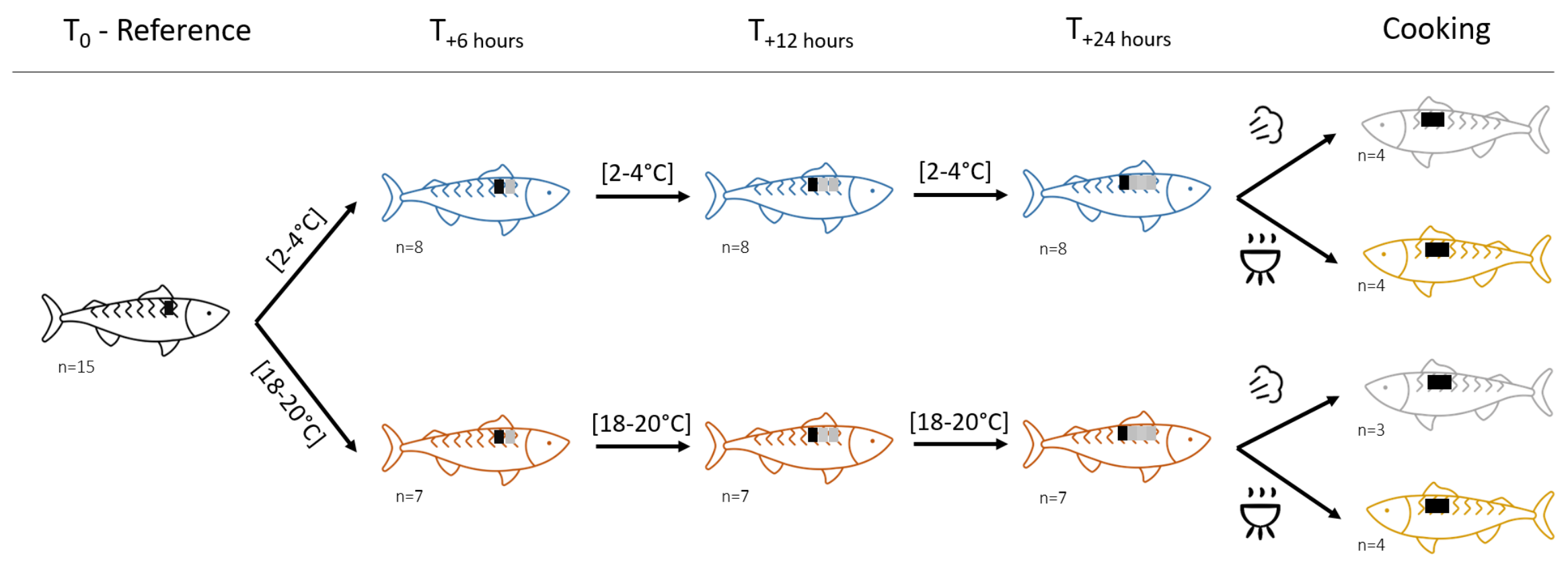

Fig. 1 Outline of the sampling design testing for the influence of storage temperature $\left(2-4^{\circ} \mathrm{C}\right.$ and $18-20^{\circ} \mathrm{C}$ ), storage duration (from $\mathrm{T}_{6}$ to $\mathrm{T}_{24}$ hours), and cooking method (grill and steam) on the fatty acid content of the Atlantic mackerel Scomber scombrus. Dark squares indicate the muscle sampling position at each step, and the grey ones the previously sampled positions. For cooking, we sampled the left side of the fish. 


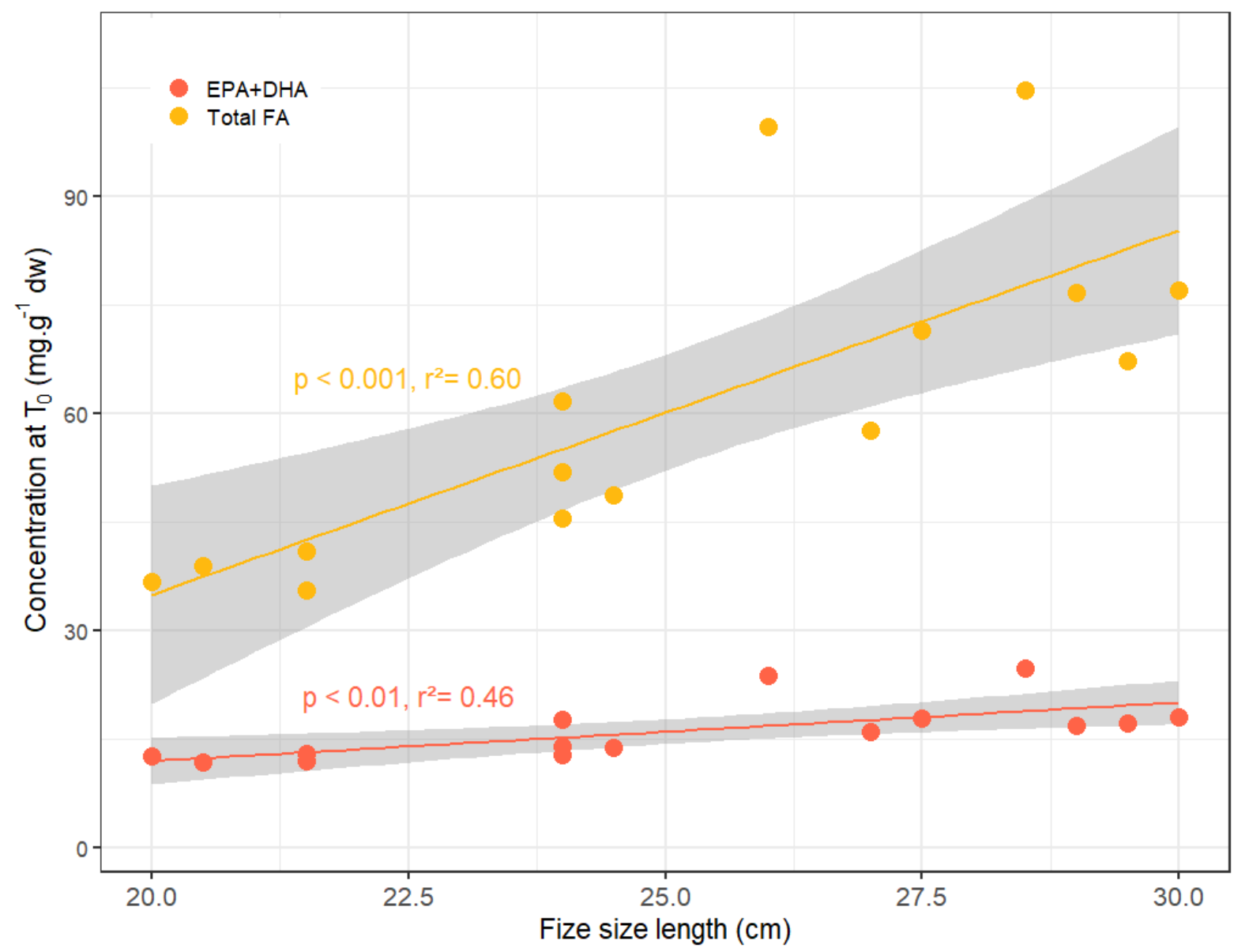

Fig. 2 Total fatty acids (FA) and EPA+DHA contents (in $\mathrm{mg}^{-\mathrm{g}^{-1}}$ of dry weight) in the dorsal fillet of Atlantic mackerel Scomber scombrus as a function of fish fork length. Fish $(\mathrm{n}=15)$ were collected from the Baie de Douarnenez, France, in July 2020. Grey areas are standard errors for the linear regressions. 

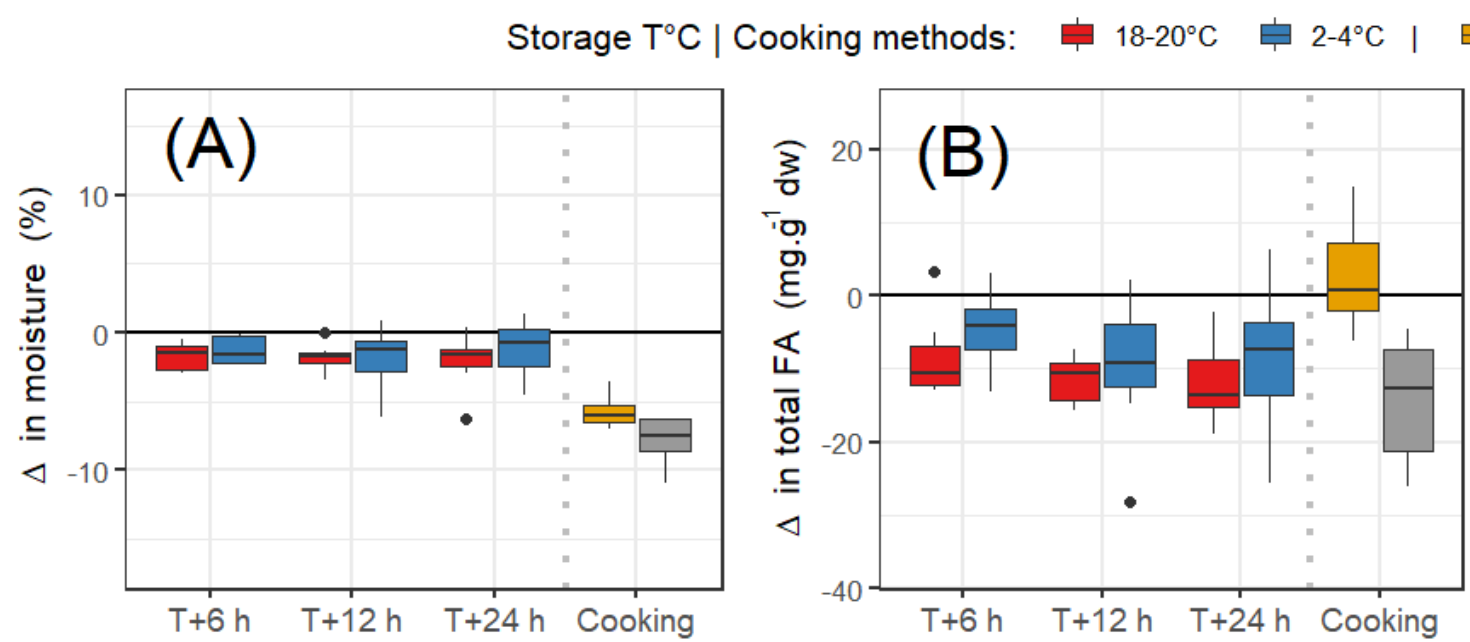

Grill 官 Steam
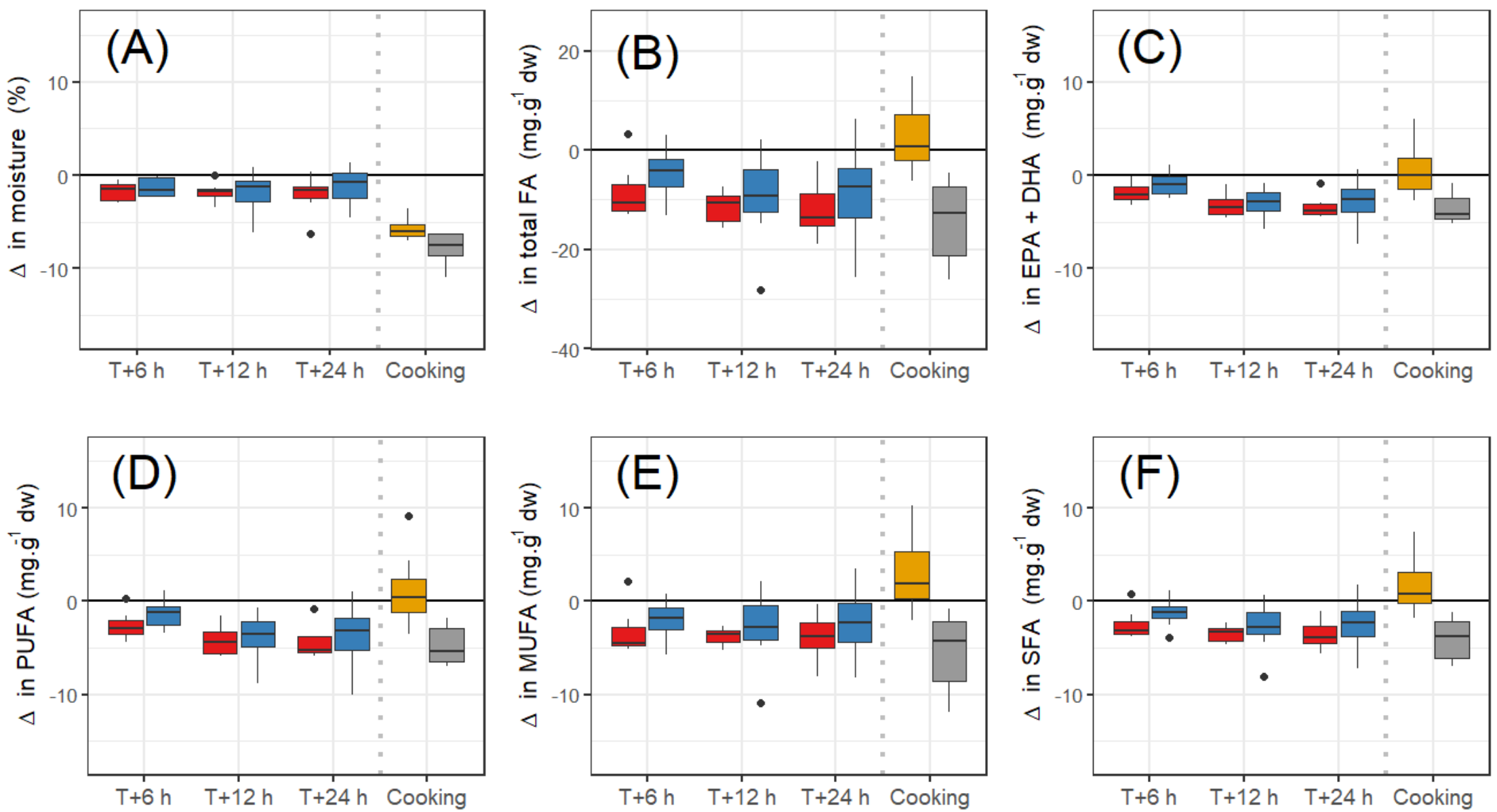

Fig. 3 Boxplots of differences from initial values ( $\mathrm{T}_{0}=$ at fish death) for dorsal fillet contents in (A) moisture, (B) total fatty acids (FA), (C) EPA+DHA, (D) poly-unsaturated FA (PUFA), (E) mono-unsaturated FA (MUFA), and (F) saturated FA (SFA) during the first post-mortem hours $\left(\mathrm{T}_{6}\right.$ to $\left.\mathrm{T}_{24}\right)$ and cooking of Atlantic mackerel, according to storage temperature and cooking methods (display by colour). In each boxplot, the thick black bar represents the median value, the box contains $50 \%$ of the data, and dots are outliers. 
Table 1 | Mean \pm standard deviation for moisture in \% per wet weight, total fatty acids (FA), EPA+DHA, poly-unsaturated FA (PUFA), monounsaturated FA (MUFA), and saturated FA (SFA) contents in $\mathrm{mg}^{-\mathrm{g}^{-1}}$ dry weight (dw), from the dorsal fillet of Atlantic mackerel after three storage durations $\left(\mathrm{T}_{6}, \mathrm{~T}_{12}\right.$, and $\mathrm{T}_{24}$ hours) at two storage temperatures $\left(2-4^{\circ} \mathrm{C}\right.$ and $\left.18-20^{\circ} \mathrm{C}\right)$, and after two cooking methods (grill and steam). $\mathrm{N}$ is the number of individuals.

\begin{tabular}{|c|c|c|c|c|c|c|c|c|c|}
\hline & \multirow{3}{*}{$\begin{array}{l}\text { Reference } \\
T_{0}\end{array}$} & \multicolumn{6}{|l|}{ Storage test } & \multicolumn{2}{|c|}{ Cooking method } \\
\hline & & \multicolumn{2}{|c|}{$\mathrm{T}_{6}$} & \multicolumn{2}{|c|}{$\mathrm{T}_{12}$} & \multicolumn{2}{|c|}{$\mathrm{T}_{24}$} & \multirow[b]{2}{*}{ Grill } & \multirow[b]{2}{*}{ Steam } \\
\hline & & {$\left[2-4^{\circ} \mathrm{C}\right]$} & {$\left[18-20^{\circ} \mathrm{C}\right]$} & {$\left[2-4^{\circ} \mathrm{C}\right]$} & {$\left[18-20^{\circ} \mathrm{C}\right]$} & {$\left[2-4^{\circ} \mathrm{C}\right]$} & {$\left[18-20^{\circ} \mathrm{C}\right]$} & & \\
\hline N & 15 & 8 & 7 & 8 & 7 & 8 & 7 & 8 & 7 \\
\hline Moisture (\%) & $75.4 \pm 3.0$ & $73.5 \pm 2.9$ & $74.3 \pm 3.4$ & $72.9 \pm 4.3$ & $74.3 \pm 3.3$ & $73.7 \pm 3.2$ & $74.0 \pm 4.7$ & $69.2 \pm 2.7$ & $68.3 \pm 3.1$ \\
\hline Total FA (mg.g $\left.\mathrm{g}^{-1} \mathrm{dw}\right)$ & $60.9 \pm 21.8$ & $60.6 \pm 19.5$ & $48.0 \pm 20.5$ & $55.6 \pm 24.4$ & $44.8 \pm 22.3$ & $56.7 \pm 22.7$ & $44.5 \pm 25.8$ & $66.5 \pm 21.0$ & $46.9 \pm 19.7$ \\
\hline EPA+DHA (mg. $\left.g^{-1} d w\right)$ & $16.2 \pm 4.0$ & $15.9 \pm 3.6$ & $13.6 \pm 3.8$ & $13.8 \pm 4.3$ & $12.3 \pm 4.4$ & $14.0 \pm 4.0$ & $12.1 \pm 5.2$ & $16.5 \pm 4.2$ & $12.9 \pm 4.1$ \\
\hline PUFA (mg.g $\left.g^{-1} \mathrm{dw}\right)$ & $20.6 \pm 5.6$ & $20.3 \pm 5.3$ & $17.0 \pm 5.2$ & $17.7 \pm 6.1$ & $15.4 \pm 5.9$ & $17.9 \pm 5.5$ & $15.3 \pm 7.0$ & $21.6 \pm 6.0$ & $16.3 \pm 5.6$ \\
\hline MUFA (mg.g $\left.g^{-1} d w\right)$ & $17.9 \pm 10.1$ & $18.0 \pm 9.3$ & $12.4 \pm 9.3$ & $17.1 \pm 11.6$ & $11.8 \pm 9.9$ & $17.6 \pm 11.0$ & $11.8 \pm 11.2$ & $20.8 \pm 9.2$ & $12.3 \pm 9.2$ \\
\hline SFA $\left(m g \cdot g^{-1} d w\right)$ & $16.2 \pm 6.3$ & $16.0 \pm 5.5$ & $12.3 \pm 6.0$ & $14.6 \pm 7.0$ & $11.4 \pm 6.5$ & $14.9 \pm 6.4$ & $11.3 \pm 7.5$ & $17.8 \pm 6.0$ & $12.1 \pm 5.5$ \\
\hline
\end{tabular}


Table 2 | Summary of the results obtained from the repeated MANOVA to test the influence of storage temperature, duration and their interaction on biochemical contents of Atlantic mackerel dorsal fillet (moisture, total fatty acids (FA), EPA+DHA, poly-unsaturated FA (PUFA), mono-unsaturated FA (MUFA), and saturated FA (SFA)).

\begin{tabular}{|c|c|c|c|}
\hline & $\chi^{2}$ & $d f$ & $\mathrm{p}$ value \\
\hline \multicolumn{4}{|l|}{ Moisture } \\
\hline Storage temperature & 0.3 & 1 & 0.580 \\
\hline Storage duration & 35.5 & 3 & $<0.001$ \\
\hline Storage temperature ${ }^{*}$ duration & 2.4 & 3 & 0.530 \\
\hline \multicolumn{4}{|l|}{ Total FA } \\
\hline Storage temperature & 0.9 & 1 & 0.332 \\
\hline Storage duration & 68.6 & 3 & $<0.001$ \\
\hline Storage temperature ${ }^{*}$ duration & 2.9 & 3 & 0.400 \\
\hline \multicolumn{4}{|l|}{$\mathrm{EPA}+\mathrm{DHA}$} \\
\hline Storage temperature & 0.7 & 1 & 0.409 \\
\hline Storage duration & 127.4 & 3 & $<0.001$ \\
\hline Storage temperature $*$ duration & 3.6 & 3 & 0.305 \\
\hline \multicolumn{4}{|l|}{ PUFA } \\
\hline Storage temperature & 0.8 & 1 & 0.384 \\
\hline Storage duration & 101.0 & 3 & $<0.001$ \\
\hline Storage temperature ${ }^{*}$ duration & 3.3 & 3 & 0.342 \\
\hline \multicolumn{4}{|l|}{ MUFA } \\
\hline Storage temperature & 1.0 & 1 & 0.318 \\
\hline Storage duration & 44.8 & 3 & $<0.001$ \\
\hline Storage temperature ${ }^{*}$ duration & 2.2 & 3 & 0.533 \\
\hline \multicolumn{4}{|l|}{ SFA } \\
\hline Storage temperature & 1.0 & 1 & 0.328 \\
\hline Storage duration & 73.1 & 3 & $<0.001$ \\
\hline Storage temperature ${ }^{*}$ duration & 4.0 & 3 & 0.266 \\
\hline
\end{tabular}

